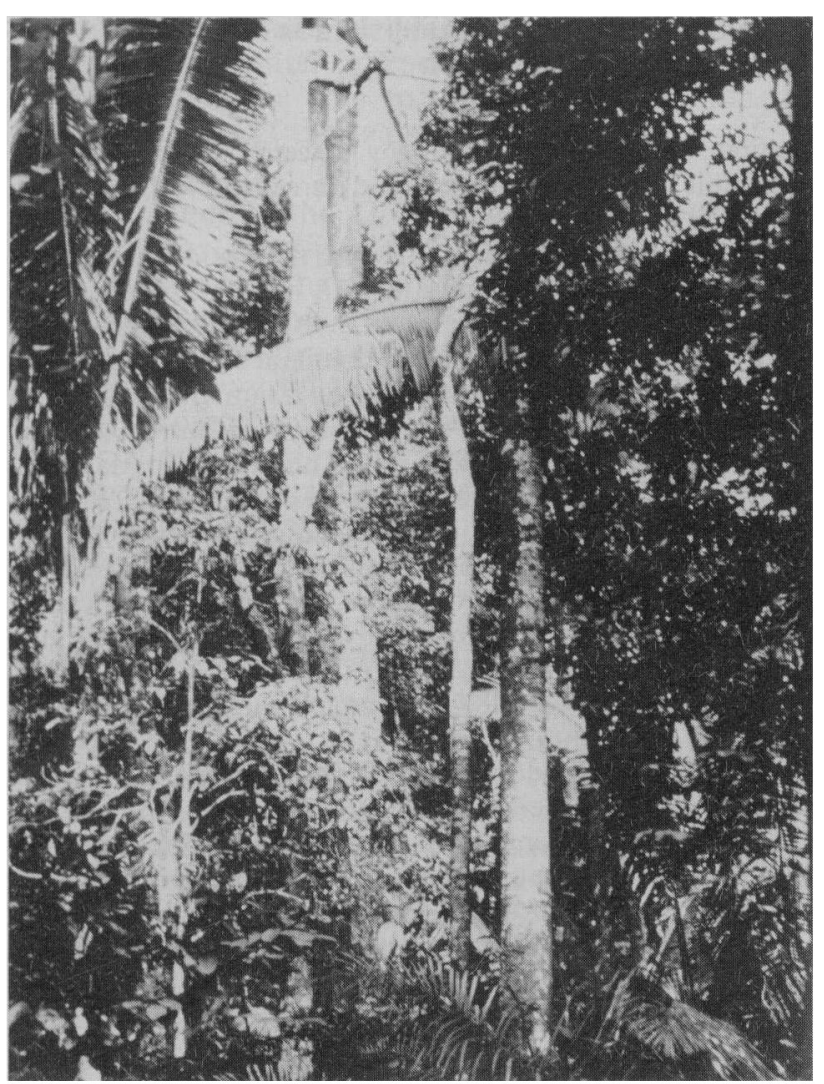

FIG. 2. Another view in the Reserve.

Photo: Professor Philip M. Fearnside. forcing small farmers to leave. Wealthy ranchers and speculators are also attracted to Amazonia, where their land-claims are secured by replacing the rain-forest with cattle pasture. Satellite data show that the deforested area in Rondonia increased from 1,217 sq. $\mathrm{km}$ in 1975 to $4,185 \mathrm{sq} . \mathrm{km}$ in 1978 , and then to 7,579 sq. $\mathrm{km}$ already in 1980 - an exponential rate that threatens to destroy all forests in the State within the present decade if continued unchanged.

The rapid deforestation in Rondônia means that the reserve was created just in time. Steep hills and the proximity of the law-enforcement authorities of Ouro Preto do Oeste have protected the land from invasion by squatters. A recentlyapproved grant from World Wildlife Fund-US will provide for construction of a formidable fence around the area, and for payment of a guard for the Reserve's first year. Construction of the fence, now under way, should be complete by the end of May 1984.

INPA's Director, Dr Henrique Bergamin Filho, has established the internal regulations of the Reserve and appointed an Administrative Council of INPA research workers. As Director of the new Reserve he has chosen the undersigned, who should be contacted by scientists who may be interested in conducting research in the Reserve.

Philip M. FEARNSIDE, Research Professor Departamento de Ecologia

Instituto Nacional de Pesquisas da Amazônia (INPA)

Caixa Postal 478

69.000 Manaus-Amazonas

Brazil.

\title{
Wetlands News from IUCN
}

Protection of the Dutch sector of the Wadden Sea, an important and vast coastal wetland bordered also by Denmark and the Federal Republic of Germany, has been given international legal status. The announcement was made by Netherlands Minister of Agriculture and Fisheries, Mr G. Braks, at the Second Conference of Parties to the 'Ramsar' Convention, held in Groningen, Netherlands, from 7 to 12 May 1984.

Three countries (Belgium, Costa Rica, and France) pledged themselves to join the Ramsar Convention 'family', which will bring the number of Contracting Parties to 38. Six others, including the USA, said they would give careful consideration to ratifying the Convention in the near future.

Not all the news was good, however: Delegates heard that Malawi had lost five of its 11 important wetlands during the last three years, and the Djoudj National Bird Park in Senegal, a World Heritage Site, is in danger of drying up unless a new channel is built. The Conference responded to the plight of wetlands conservationists in Africa and other Third World regions by calling for action from the Convention secretariat to set up a clearing house to channel money, training, and equipment, to wetland conservation projects-especially in areas that are prone to drought.

The Convention on Conservation of Wetlands of International Importance especially as Waterfowl Habitat, usually called the Ramsar Convention after the town in Iran where it was adopted, entered into force in 1975. The States that are party to the Convention accept the premise that the wise use of wetlands to serve human needs must be compatible with conservation of Nature and natural resources. In addition to a general obligation to conserve wetland areas, each has undertaken to recognize at least one prime wetland on its territory as being of international importance.

The List of Wetlands of International Importance now totals nearly 300 sites occupying some 20 million hectares. If promises made at Groningen are fulfilled, the List could swell to more than 500 sites and the area which it covers could be trebled. Thus, for example, France has pledged to designate the Camargue and many other sites already protected under national legislation, when she ratifies the Convention, while the British delegation announced that 132 sites in the UK will have been added to the List by the end of 1986 .

The Convention is currently serviced, with only token financial support from the 'States Party', by IUCN, with scientific support provided by the International Waterfowl Research Bureau. A Task-Force, composed of representatives of Canada, Denmark or Sweden, the Netherlands, Poland, Senegal, and Tunisia, has been established to help settle the question of the Convention's long-term organization and financing.

$$
\begin{aligned}
& \text { DANIEL NAVID } \\
& \text { IUCN } \\
& \text { World Conservation Centre } \\
& \text { Avenue du Mont-Blanc } \\
& \text { I196 Gland, Switzerland. }
\end{aligned}
$$

